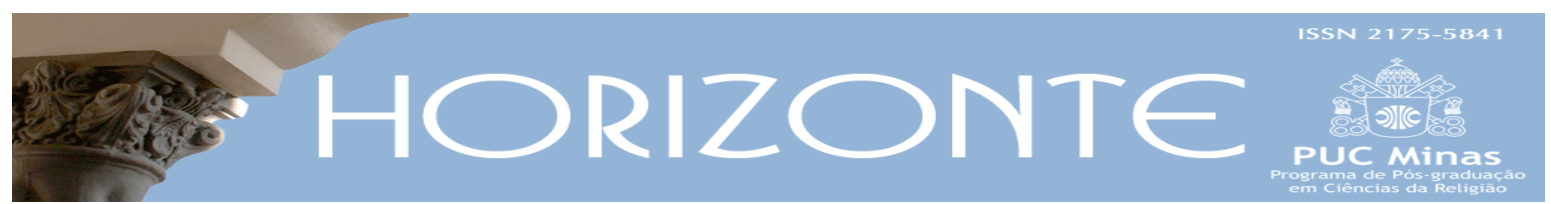

Dossiê: Fundamentalismos e Democracia - Artigo Original (c) (1) DOI - 10.5752/P.2175-5841.2020v18n57p975

\title{
Estado laico e dinâmicas religiosas no Brasil: tensões e dissonâncias
}

\author{
Secular State and religious dynamics in Brazil: tensions and dissonances
}

\author{
Marcelo Camurça* \\ Emerson José Sena da Silveira** \\ Péricles Morais de Andrade Júnior ${ }^{* * *}$
}

\begin{abstract}
Resumo
Este texto busca examinar as tensões e dissonâncias na relação entre religião e espaço público no Brasil contemporâneo. Partindo de uma sociologia e antropologia dos fenômenos da secularização e da laicidade, pretende demonstrar a porosidade do sistema público/político brasileiro com o meio religioso. Recorrendo a uma perspectiva sócio-histórica procura compreender como as fronteiras entre religião e política no Brasil foram precariamente construídas ao longo da constituição do nosso Estado, sem nunca haverem sido institucionalmente bem demarcadas. Vácuo, que gerou concessões por parte do Estado às religiões majoritárias cristãs, assegurando legitimidade pública à seus símbolos religiosos nos espaços estatais, à princípio, neutros e seculares. Entretanto a Constituição de 1988, representou o influxo de uma legislação moderna e laica que legitimou sujeitos de direitos como mulheres, negros, índios, LGBTs, ambientalistas, etc. Diante deste quadro, esta reflexão ambiciona contribuir para a interpretação da complexidade que significa a presença múltipla e contraditória na esfera pública, tanto das religiões majoritárias cristãs, assentadas em uma agenda de valores religiosos conservadores quanto de projetos liberais e libertários acionados por segmentos da sociedade civil e agentes públicos gerando tensões e dissonâncias. Para compreender esta realidade, enquanto mosaico de interações e antagonismos, buscar-se-á trabalhar com a noção de pluriconfessionalidade do sociólogo mexicano Roberto Blancarte; assim como com aquelas de laicidade "de reconhecimento" e de "integração" do cientista político francês Philippe Portier. Com isto, procura-se aproximar teórica e empiricamente de uma compreensão mais ampla e nuançada do nosso sistema público-político na relação com a dimensão religiosa.
\end{abstract}

Palavras-chave: Brasil. Religião. Espaço público. Tensão. Pluriconfessionalidade. Estado Laico.

\begin{abstract}
This text examines the tensions and the dissonances in the relation between religion and public sphere in contemporary Brazil. Based on a Sociology and on an Anthropology of the phenomena of secularization and secularity, the purpose is to demonstrate the "porosity" of the Brazilian public/political system with the religious milieu. By applying a socio-historical perspective, the work attempts to understand how the boundaries between religion and politics were precariously constructed throughout the constitution of our State in Brazil, without ever having been institutionally well-delimited. This vacuum, which generated concessions on the part of the State to major Christian religions, guaranteed public legitimacy to their religious symbols in official state spaces, which are, in principle, neutral and secular. However, the 1988 Constitution represented the influx of modern and secular legislation that legitimized subjects of rights such as women, black people, indigenous peoples, LGBTs, environmentalists, etc. Given that background, this reflection aims at contributing to the interpretation of the complexity involved in the multiple and contradictory presence - in the public sphere - of both major Christian religions - which are based on an agenda of conservative religious values - and liberal and libertarian projects organized by segments of civil society and public agents, which generate tensions and dissonances. To understand this reality - as a mosaic of interactions and antagonisms -, we work with the notion of "pluri-confessionality" of Mexican sociologist Roberto Blancarte and also with the notions of secularity of "recognition" and of "integration" of French political scientist Philippe Portier. Hence, we attempt to reach theoretically and empirically a broader and nuanced understanding of our public-political system in the relation with the religious dimension.
\end{abstract}

Keywords: Brazil. Religion. Public sphere. Tension. Pluri-confessionality. Secular state.

Artigo submetido em 17 de julho de 2020 e aprovado em 9 de fevereiro de 2021.

* Doutor em Antropologia pelo Museu Nacional - UFRJ. Professor titular aposentado da UFJF. País de origem: Brasil. E-mail: mcamurca@terra.com.br

${ }^{* *}$ Doutor em Ciência da Religião pela UFJF. Professor do PPCIR-UFJF. País de origem: Brasil. E-mail: emerson.pesquisa@gmail.com

${ }^{* * *}$ Doutor em Sociologia pela UFPE. Professor do PPGCR da UFS. País de origem: Brasil. E-mail: periclesmorais@hotmail.com

Horizonte, Belo Horizonte, v. 18, n. 57, p. 975-1001, set./dez. 2020 - ISSN 2175-5841 


\section{Introdução}

Através de um sobrevoo na trajetória histórica da presença pública da religião no Brasil, podemos afirmar que hoje o modelo de relação Estado-Igreja no país se encontra marcado pela influência de uma matriz cristã, partilhada entre catolicismo e evangelismo/pentecostal na esfera pública. Podemos deduzir ainda que sem a existência de um Estado confessional, do ponto de vista formal, estas expressões cristãs majoritárias exercem um poder de fato na política e nas decisões de Estado (RANQUETAT JÚNIOR, 2013, p. 98).

Dentro de nossa perspectiva analítica - que combina uma mirada histórica sobre o fenômeno, articulada a um experimento de análise da atualidade enquanto um quadro multifacetado com a presença de atores religiosos cristãos conservadores $^{1}$ bastante fortalecidos, religiosos em sintonia com o projetos modernos, segmentos laicos da sociedade civil e agentes público, todos em disputa e negociação sobre seu papel no espaço público e na relação com o Estado - este artigo busca diagnosticar as tensões e dissonâncias na relação entre religião e política no Brasil. Ele leva em conta uma perspectiva comparatista com processos de regulação do religioso em outras partes do mundo. Dentro da formulação de David Martin, existiram no Ocidente duas experiências históricas paradigmáticas do Estado regular o religioso: a da França, onde o Estado laico se constituiu contra a religião (católica) vinculada ao regime da monarquia de "direito divino" e a dos EUA, onde o Estado laico se moldou a favor da religião, para defender a pluralidade religiosa contra o monopólio de uma sobre as demais (MARTIN, 1990). É possível perceber a polissemia histórica do conceito de laico, que abordaremos ao longo do texto. Essas duas modalidades do laico influenciam, enquanto modelos, as variações de regimes de laicidade - mais flexíveis ou mais rígidas - e, no segundo

\footnotetext{
${ }^{1}$ Adotamos aqui a ideia de que o conservadorismo, em si, é um amplo movimento de ideias e práticas sociais, distribuído por um vasto leque de exemplos empíricos que tem a ver com as reações ao mundo moderno e as suas mudanças sociais e culturais, ou seja, a autonomias das esferas de valor, em termos weberianos, do controle das instituições e hierarquias sacralizadas (ciência, arte, política, sexualidade etc.). Em essência, os conservadores são aqueles, sob a ótica das teorias esgrimidas no artigo, se dedicam a tentar conservar, e a repor, a visão de mundo lastreada na reação à modernidade. Os reacionários, por outro lado, dão um passo à mais, vão à guerra para restaurar uma suposta ordem, sob a hegemonia das instituições religiosas, no caso, cristãs, idealizada e inexistente, de vida social, moral, cultural, sexual, familiar e política.
} 
caso, podem ser reinterpretadas por setores religiosos influentes nos seus países como uma forma de exigir privilégios e/ou de forjar uma situação de confessionalidade não explícita.

Então, nosso intento neste artigo é refletir, no caso do Brasil, sobre essa característica do nosso sistema público/político em absorver as estratégias/intervenções do meio religioso no seu seio. Nossa intenção é compreender como as fronteiras entre religião e política foram precariamente construídas, sem nunca haver sido plenamente demarcadas, embora, em termos normativos, houvesse marcos legais e institucionais, ainda que esporádicos e pontuais. Isto gerou concessões por parte do Estado às religiões majoritárias, que terminaram por conferir legitimidade pública a símbolos religiosos de matriz cristã em espaços por princípio, universais e seculares. ${ }^{2}$

Em um período recente, pós Constituição de 1988, movimentos sociais organizados da sociedade civil aliados a agentes públicos lograram estabelecer na forma da lei, alguns direitos civis e reprodutivos nos campos da saúde, educação, sexualidade etc. - muitas vezes em tensão com uma moral religiosa estabelecida. Porém, de forma geral, não houve ao longo da história republicana, a fixação de princípios jurídico-políticos que esclarecessem os contornos da separação Igreja(s) - Estado e o lugar mais preciso da religião na esfera e no espaço público.

Neste sentido, este artigo ambiciona contribuir para a interpretação das atuais tensões provocadas pela iniciativa das religiões (cristãs) majoritárias do Brasil de aumentar sua influência sobre esferas que historicamente se

\footnotetext{
${ }^{2}$ A amplidão do conceito de secular nos impede de, no espaço de um artigo, trazer toda complexidade e história do conceito. Secular aqui tem a ver com a emergência da estrutura social e cultural da modernidade emancipada do controle (semântico e político) religioso institucional. Secular, secularização etc., em nosso artigo, tem a acepção clássica, mas temperada por críticas: processo de autonomia do mundo em relação as ideias e estruturas religiosas institucionais e as reações destas aos processos secularizantes. Desde os marcos clássicos, como Peter Berger e seu livro O Dossel Sagrado (1985), a polêmica acentuou, com muitas posições intermediárias, ora acentuando a radicalidade do termo, e seu correspondente na realidade, ora amenizando e propondo um gradiente - reencantamento - para compreender os matizes empíricas. O próprio Peter Berger (2017), no livro Múltiplos altares da Modernidade, reviu seu antigo conceito de secular e de secularização - substantivo e adjetivo, conceito e processo - e mostrou como os discursos religiosos não se tornaram privados e restritos, expulsos da esfera pública. Ao contrário, eles reagiram aos processos secularizastes e se tornaram agentes influenciadores. A presença e atuação dos grupos cristãos (católicos e evangélicos) na esfera pública - sejam grupos mais próximos da luta pela igualdade social e universalização efetiva dos direitos humanos ou mais próximos da defesa moralista e de supostas hierarquias naturais -, mostra que determinado tipo de religião se recusou a ser algo privado e individual.
} 
emanciparam do seu controle (sistema escolar, sanitário, científico etc.). Isto se dá porque este cristianismo conservador quer influenciar, e hegemonizar seu controle, a partir de interesses próprios, a agenda das políticas públicas de áreas não-diretamente religiosas autônomas. Ou seja, circunscritos a questões de cunho moral e valores religiosos com reflexos para a família, infância, sexualidade, costumes sociais.

Do ponto de vista teórico de diagnóstico desta realidade, defende-se aqui o emprego da noção de pluriconfessionalidade, entendida como um consórcio entre católicos e evangélicos visando reforçar e justificar sua presença pública, sem questionar ostensivamente a laicidade do Estado. Esta noção foi formulada pelo sociólogo mexicano Roberto Blancarte (2011), para dar conta das transformações da presença religiosa no espaço público da América Latina. Da mesma forma, busca-se utilizar as formulações de Philippe Portier (2011) de "laicidade de reconhecimento" e "laicidade de integração" para o caso francês. Através delas, o autor mede as transformações contemporâneas na separação entre Estado e religiões da laicidade francesa, para uma atitude, primeiro, de reconhecimento das religiões por parte do Estado em determinadas circunstâncias sociais e segundo, de exigência de compromisso destas religiões reconhecidas para com as leis da República.

\section{Processo histórico no Brasil da presença religiosa no espaço público e no Estado}

Durante todo o século XX verifica-se no Brasil a presença da dimensão religiosa na esfera pública, com preeminência para o catolicismo. São exemplos eloquentes desse processo: a Liga Eleitoral Católica (1934), a Ação Católica (1935), o Partido Democrata Cristão (1945) e - numa outra direção não confessional - a atuação da Igreja Católica na defesa dos direitos humanos no período da ditadura (1964-1985). De uma presença de longo curso, que remonta o passado colonial do Brasil, a Igreja Católica diante das transformações da modernidade republicana, continuou a exigir a partir dos anos 1900, sua presença forte no Estado na forma de 
"Neocristandade" 3. Esta atitude se flexibiliza no período pós Concílio Vaticano II dos anos 1960/70 onde aceita as mediações da modernidade e autonomia das instituições seculares, porém chega aos anos 1980/1990 em setores expressivos de sua estrutura a um revival na sua pretensão de imprimir um cunho marcadamente religioso à sociedade e ao Estado brasileiro. Postura confessional, ainda que temperada pelas técnicas do mundo contemporâneo, da internet, consumo e estilo midiático do “Papa-pop” João Paulo II.

Neste período dos anos 1990-2000 no Brasil, os setores ditos "progressistas" 4 do catolicismo, fecundados na abertura à modernidade secular do Concílio Vaticano II, perderam espaço, devido à forte intervenção do Pontificado conservador de João Paulo II. O discurso explicitamente social e engajado do clero, bispos e leigos progressistas dos anos 1970, início dos 1980, foi paulatinamente confrontado pelo da "espiritualidade" aliado a reafirmação dos valores e práticas religiosas tradicionais por parte da Cúria Romana e dos setores da hierarquia e clero conservadores. Durante os pontificados de João Paulo II e Bento XV com a clara emulação provocada pelo avanço pentecostal, o catolicismo deslocou-se para ainda mais longe de identidade forjada pelo discurso da "teologia da libertação" (BURITY, 2006). Entre 1990-2010 observa-se uma ocupação crescente da arena pública/política por seus segmentos carismáticos e midiáticos, na esteira do "avanço evangélico/pentecostal" para se confrontar com novos atores laicos surgidos na sociedade civil, sobretudo os movimentos identitários 5 (MACHADO,

\footnotetext{
${ }^{3}$ Termo que designa, com o prefixo "neo", uma recuperação da Cristandade medieval, ou seja, um domínio da Igreja Católica na ideologia, política e poder do Estado e na sociedade. Está associado ao projeto da "Romanização" ou "restauração católica", uma reforma interna da Igreja para torná-la mais monolítica, visando à intervenção e recuperação dos privilégios que tinha nos períodos colonial e imperial do Brasil, sem a necessidade da submissão do "Padroado" ao Imperador (AZZI, 1994).

${ }^{4}$ Adotaremos como significado para este termo a ideia de que progressismo, progressistas etc., quando na esfera religiosa institucional, referem-se a setores que se abrem ao mundo moderno e as suas propostas relativas à justiça e igualdades social e a ampliação dos direitos humanos para minorias historicamente alijadas, como os indígenas. $\mathrm{O}$ termo, no entanto, pode dar a falsa ideia de que há um vetor crescente e otimista de progresso social. Neste artigo, toda nebulosa do termo "progressistas" (e derivados), tem a ver com a influência das ideias socialistas, marxianas, distributivistas, economia solidária, críticas às dificuldades da extensão da cidadania aos setores marginalizados (negros, LGBTQAls, mulheres, camponeses, povos originários), sobre amplos setores religiosos cristão e nãocristãos. É de se notar que por essa veia, a ideia de laico como autônomo em relação ao religioso, ganha especial relevo.

${ }^{5}$ De acordo com Marcelo Ennes e Frank Marcon, os movimentos identitários ganham visibilidade e expressão a partir das mudanças políticas e culturais observadas nas últimas cinco décadas, sobretudo a partir daquelas produzidas pelas transformações do chamado mundo moderno, que inclui a crise das metareferências, a emergência de novos sujeitos que passaram a formular e lutar por uma nova agenda política e o desenvolvimento de teorias sociais explicativas sobre a constituição dos grupos sociais e das diferenças entre eles (2014, p.274-305).
} 
2012) ${ }^{6}$. No entanto, a partir de 2013 com a eleição do Papa Francisco, uma orientação voltada para os deserdados, imigrantes, preocupada com o meio ambiente e com uma sintonia com os costumes morais da modernidade, intenta no comando da Igreja, contrabalançar esta tendência conservadora.

Os episódios sócio-históricos-religiosos brevemente relatados acima levamnos à tarefa de refletir sobre as vozes e conflitos emergentes no espaço público no nosso país. O primeiro deles resulta da presença dogmática da religião e de seus agentes no cenário público contemporâneo. Essa presença implica em polaridades éticas (palavra divina $\mathrm{x}$ autonomia humana), em concepções religiosas de moral individual e familiar numa concorrência de significado pela plausibilidade social com esferas laicas (políticas, científicas) da sociedade. A presença e a circulação de discursos religiosos tradicionais no espaço público intensificam dissonâncias culturais e conflitos de poder. Produzem efeitos de busca pela ancestralidade. Nesse sentido, o discurso da tradição deflagra uma reação de retóricas e práticas antagônicas provindas de segmentos modernos. Com isso, dissemina controvérsias, ressignifica identidades e trajetórias tanto individuais quanto coletivas.

Estas questões não podem ser separadas da dinâmica de formação da sociedade brasileira e à estruturação do Estado no país. Trata-se de uma sociedade cujas práticas e crenças mágicas, místicas e religiosas combinam, conflitam e articulam-se aos processos e às tecnologias seculares nos mais variados campos, como economia, política, arte, ciência e meios de comunicação. Dessa forma, nem francesa, nem norte-americana, a laicidade brasileira hoje se equilibra entre o projeto low profile de um Estado Laico com baixa expectativa de uma secularização da sociedade; a tenaz ofensiva religiosa de grupos religiosos (evangélicos e católicos) e a contrapressão de grupos militantes identitários e setores laicos

\footnotetext{
${ }^{6}$ Sabemos das diferenças semânticas entre os conceitos de laicidade, mas, neste artigo, optamos pelos conceitos postos por pesquisadores como Mariano (2011), Portier (2011) e Blancarte (2010). A chave para pensar o laico não se reduz à sua normatividade, mas segue além e aponta para a influência da esfera pública sobre a normatividade do laico. Por essa chave, entendemos como os atores religiosos ganharam visibilidade e empoderamento na luta para dar a Constituição de 1988 uma feição laica. Segundo Mariano (2011, p.252), se colocaram na "defesa da laicidade contra interferências religiosas na educação, na saúde, no corpo, nas pesquisas científicas, no ordenamento jurídico-político e nos órgãos estatais". Eram compostos por "cientistas, juristas, artistas, feministas, homossexuais, jornalistas, educadores, políticos, autoridades e gestores públicos alocados nos Ministérios da Educação e da Saúde, na Secretaria dos Direitos Humanos e de Política para mulheres" (2011, nota 4, p.252).
} 
(jurídicos, científicos, acadêmicos) organizados na sociedade e no Estado (CAMURÇA, 2017; MARIANO, 2011).

Se um espaço público é aquele proporcionado por uma supervisão laica do Estado, emancipado de influência religiosa e portador de neutralidade em relação a todos os componentes da sociedade, a laicidade e a secularização7 formam algumas das vértebras constituintes da dimensão pública no mundo ocidental moderno. No entanto, devido à diversidade de processos para atingir esse fim, torna-se necessário situar as histórias dos espaços públicos, heterogêneos e dinâmicos, tanto no nível das nacionalidades, quanto no das regionalidades ${ }^{8}$.

Esses processos diferenciados, ora em disputa, ora em aliança envolvendo agentes e instituições religiosas, estruturaram o espaço público e suas tendências progressistas ao longo da história. Exemplos destes arranjos pululam em diversos lugares do globo. Mesmo na Europa, onde os princípios de uma modernidade clássica e da fixação de uma laicidade de separação Igreja-Estado pareciam consolidados, transformações surpreendem. Philippe Portier, ao tratar da situação do regime da regulação do religioso na Europa, revela uma tendência crescente a se chegar a um "modelo compartilhado de organização da relação Igrejas/Estado" (2011, p. 2-13). Nos países ditos confessionais - que adotam uma "religião de Estado” (Inglaterra, Dinamarca, Grécia), constata-se uma abertura na direção a um "pluralismo religioso igualitário", ao passo que nos países de separação entre Igrejas e Estado (França, Alemanha, Bélgica, Holanda), verifica-se uma política crescente de reconhecimento do papel das religiões no domínio público (PORTIER, 2011, p. 11-23). O cientista político português Fernando Catroga, por sua vez, fala

\footnotetext{
${ }^{7}$ Este texto toma as noções de secularização e laicidade da seguinte forma. Secularização: processo histórico-social que implica na redução de influência da religião no tecido social. Laicidade: processo jurídico-político que redunda na separação do Estado da Igreja, onde este passa a se reger por concepções filosófico/políticas/ científicas na sua gestão da sociedade.

${ }^{8}$ Embora sejam processos diversos, complexos e de longa duração, secularização e laicidade carregam também alta densidade cultural/simbólica e valorativa, misturando-se, portanto, aos desejos sociais. Ambos os conceitos deitam fortes raízes em duas longas tradições socioculturais: a cristã e a grega. Ao longo das sucessivas crises e mutações das culturas e sociedades ocidentais, esses conceitos alargaram-se e designaram novas realidades histórico-antropológicas. A face pública dessas novas realidades emerge na modernidade, horizonte simbólico e material do mundo ocidental pós-cristão. Em meio a isto, processos sociais violentos e conflitivos estruturam tanto a secularidade quanto a laicidade. Exemplos disso são os embates da Reforma Protestante (1917) e os da Revolução Francesa (1789). Estes estabeleceram não só o desencantamento do ethos simbólico-político-social dos Estados Absolutistas de "direito divino", mas também o recuo do poder da Igreja Católica na educação, na cidadania e em outros setores sociais.
} 
de uma "quase laicidade" para os países católicos europeus: Portugal, Espanha e Itália (CATROGA, 2010).

Por sua vez, secularização e laicidade tornaram-se não apenas categorias analíticas, mas um programa social, um "dever-ser", de forma que o secularismo e o laicismo emergiram como militâncias sociais ante a manutenção ou ingerências religiosas de (re)conquista da vida social, cultural, científica e ética. Se a sociedade democrática contém conflitos, pressões e mobilizações, o espaço público 9 é o lugar onde se expressa esta democracia, território onde estão alocados: grupos, indivíduos, classes sociais, atravessado por fluxos e refluxos, manifestações e trânsitos.

No caso brasileiro, a possibilidade de se pensar em espaço público surge com a separação entre a Igreja Católica e o Estado, efetivada logo após a Proclamação da República brasileira (1889), pondo fim ao longo Regime do Padroado (Império e Igreja Católica em simbiose social e política). Nosso regime inicial de laicidade foi estabelecido a partir da Constituição de 1891, que adotou princípios de laicidade tout court a partir do caso francês em conjugação com o norte-americano ${ }^{10}$ na forma de instituir a separação jurídica entre Estado e Igreja ${ }^{11}$. Entretanto, ao longo do século XX essas medidas laicizantes mais restritas foram sendo flexibilizadas.

A partir da Constituição de 1934 adotou-se o modelo de colaboração recíproca entre Estado e Igreja, com criação de feriados religiosos, reconhecimento dos efeitos civis do casamento religioso, permissão de cemitérios religiosos,

\footnotetext{
${ }^{9}$ Tomamos aqui, a noção habermasiana de espaço público como o lugar além do privado onde ocorrem às relações sociais e os embates discursivos, controvérsias visando se obter legitimidade social (HABERMAS, 2003).

10"Costuma-se opor, em se tratando de religião, a Constituição de 1891 à de 1934, inclusive por suas referências, americana na primeira, alemã na outra. Seus conteúdos mostrariam a transição de uma concepção predominantemente 'laicista', emblematizada pelo preâmbulo que não faz referência a 'Deus', para outra em que predominam os 'privilégios' à religião e permite a 'cooperação' entre Estado e Igrejas" (GIUMBELLI, 2002, p, 242). "Enfim, nossa república parece ter sido mais 'republicana' que a francesa configurando aqui um projeto abrangente e concentrado de laicização" (GIUMBELLI, 2002, p, 244-45).

${ }^{11}$ Dentro desta perspectiva, estabeleceu: 1) que o Estado não mais assumiria uma religião oficial; 2) a inviolabilidade da liberdade de consciência e de crença, impedindo que as pessoas fossem privadas de seus direitos por motivo de crença religiosa, salvo se invocadas para se eximirem de obrigação legal a todos imposta; 3) que as eleições para esferas do poder estatal não ocorreriam mais dentro das igrejas; 4) que o governo não interferiria mais na escolha de cargos do alto clero; 5) extinguiu-se a definição de paróquia como unidade administrativa; 6) que o monopólio de registros civis fosse encargo do Estado; 7) a criação de cemitérios públicos; 8) que o Estado também assumisse a educação, instituindo várias escolas públicas de ensino fundamental e médio; 9) exclui totalmente o ensino religioso das escolas públicas: parágrafo $6^{\circ}$, do artigo 72 , da Constituição: "será leigo o ensino ministrado nos estabelecimentos públicos" (GIUMBELLI, 2008).
} 
inclusão da disciplina confessional nas escolas e o serviço militar alternativo para os eclesiásticos. Gradativamente os privilégios católicos, em detrimento das demais religiões minoritárias, foram reforçados com auxílios financeiros para suas obras beneficentes, isenções de impostos e parcerias com as instâncias governamentais. E como culminância simbólica, desta "discriminação positiva" para com a Igreja Católica, por parte do Estado (ORO, 2011, p. 229) recrudesceu-se a presença dos crucifixos nas repartições públicas e a ereção da estátua majestosa do Cristo Redentor no topo da capital federal (OLIVEIRA, 1992, p. 42; GIUMBELLI, 2014). Portanto, se pensarmos numa escala da história longa do país, tem-se que concordar com Montero sobre o poder desigual da Igreja Católica, frente às outras religiões, pela sua capacidade de influir na agenda política devido a sua eficácia de transformar valores religiosos em normas jurídico/políticas da nação (2012, p. 172).

Isto, contudo, foi questionado e relativizado pelo avanço evangélicopentecostal a partir dos anos 1980, primeiramente no campo religioso brasileiro e em seguida no espaço e esfera pública ${ }^{12}$. Com uma atuação proselitista, visando uma conversão de caráter exclusivista da população - no estilo, "sou evangélico", logo não frequento nenhuma outra religião - os evangélicos pentecostais implantaram, de forma definitiva, o pluralismo religioso e o mercado concorrencial entre as religiões no Brasil, rompendo com o monolitismo católico (MARIANO, 2011, p. 248). E dentro disto, passaram a exigir do Estado, invocando o princípio da laicidade, uma equidade de tratamento entre as religiões no Brasil, leia-se entre eles, evangélicos e os católicos. Enfim, o que Blancarte chamará de "pluriconfessionalidade".

O Estado Moderno no Brasil, idealmente, esfera política autônoma, mas de fato extremamente permeável às forças socioculturais-religiosas do país vem sendo então marcado pela seguinte dinâmica. De um lado, pela centenária hegemonia do

\footnotetext{
${ }^{12} \mathrm{O}$ leitor poderá observar que neste texto nos referimos, ora a espaço público, ora a esfera pública. Embora sejam conceitos conexos, não são sinônimos, existindo diferenças entre estes. Seguimos, nesta diferenciação, a formulação da antropóloga Ana Paula Miranda (2009, p. 125-152) para quem, "esfera pública, é entendida como o universo discursivo no qual ideias e normas são difundidas e submetidas ao debate público, já o conceito de espaço público equivale ao campo de relações, fora do espaço doméstico, onde ocorrem interações sociais" (2009, nota 5, p.145).
} 
catolicismo, recentemente vivendo certo retraimento público, mas que, no entanto, procura criar novas estratégias modernas - midiáticas e carismáticas - de reocupação do espaço público. De outro, pelo advento do evangelismopentecostalismo na sua avassaladora e patente ofensiva de ocupação do espaço público. E ainda por setores laicos (técnicos, cientistas, juristas, gestores públicos, educadores, movimentos identitários e sociais organizados, como grupos feministas, LGBTI+ e MST, MTST, etc. que desde a Constituinte de 1988, vem logrando inserir projetos de políticas públicas, sociais e de direitos, baseados em concepções seculares (MARIANO, 2011, p. 252).

Portanto, o caso do Brasil atesta, que apenas numa definição teórica exemplar da modernidade clássica: secular e religioso tem seus lugares determinados como esferas rigidamente separadas. Isto também, não foi muito diferente das experiências dos diversos países do globo, em maior ou menor grau, quando os processos de laicidade permitiram diversos arranjos. No Brasil, devido à falta de uma formulação constitucional abrangente para a regular o religioso, a situação oscilou sempre de acordo com as conjunturas, numa relação ora de maior separação ora de complementaridade e até fusão entre as duas esferas.

Apesar destas inserções laicas da Constituinte de 1988 e antes na Constituição fundadora da República de 1891, o que prevaleceu fundamentalmente, como critério para a estruturação da laicidade foi a negociação sobre os direitos e deveres com relação à Igreja Católica - a religião padrão - frente ao Estado brasileiro. Isto, ao invés da elaboração de uma política geral de regulamentação do religioso, assim como da proposição de regras de convivência das religiões entre si e destas com o Estado e a sociedade, baseada nos princípios da liberdade de consciência, de expressão e dos direitos das minorias. Portanto, o que imperou nas franjas desta indefinição, foi a constante fricção entre religioso e secular. A implantação do Estado laico desde a $1^{\text {a }}$ república em 1889, portanto, não resultou numa descristianização do espaço e esfera pública, que sempre foi impregnada de seus valores/símbolos religiosos cristãos (RANQUETAT JÚNIOR, 2013, p. 89). 


\section{Esfera pública e campo religioso no Brasil}

O processo de diferenciação das esferas sociais (política, economia, ciência, religião) dinâmica própria da modernidade, responsável pela constituição da dimensão pública, implicou no Brasil, complexos jogos simbólicos e políticos. Dentro desta problemática, práticas e cultos tidos como "magia” tiveram que se converter ao formato de "religião" para poderem se legitimar e serem reconhecidos perante o Estado brasileiro e seus poderes constituídos (MONTERO, 2006, p.4765; 2012, p.167-183). Portanto, o "dentro" e o "fora" dos campos religiosos específicos (católico, evangélico, afro-brasileiro, kardecista e outros) se encontram afetados por formas institucionais de relação com o Estado, de modo que as dinâmicas internas aos campos religiosos não podem ser pensadas sem as conexões com as esferas social e política.

Do ponto de vista das dinâmicas gestadas na interface do campo religioso com a sociedade histórica, temos que considerar a existência em terra brasilis, de uma matriz religiosa holística, mágica, sincrética e tradicional, fruto de porosidades e mútuas influências das culturas religiosas europeias, indígenas e africanas. Esse molde se constituiu como uma estrutura de longo curso, que recobriu e articulou dentro de si estas três tradições religiosas (incorporando às que vieram em seguida), ainda que, entrecortada por surtos de pertenças e identidades religiosas bem definidas, características modernas (SANCHIS, 1997; CAMURÇA, 2009).

Apesar da violência, da exploração colonial e das imposições da instituição católica, a trama histórico-estrutural formada nos eventos dos encontros simbólicos/culturais/religiosos, ainda que assimétricos e hierárquicos, deu origem a uma totalidade aberta à combinação das experiências e semânticas (mitológicas e rituais) entre as religiões (SANCHIS, 1997; CAMURÇA, 2009). Tudo isto, sob a costura dos fios do compadrio, das parentelas e da afinidade patrimonial do tecido social brasileiro. 
Constitui-se, portanto, uma força tendencial sincrética que perpassa toda sociedade ao longo de nossa história, gerando interpenetrações e combinações entre as religiões. Como contraface desta estrutura sincrética produz-se também uma reação moderna na forma de identidades bem definidas e consequentemente de disputas e competições entre estas.

Como exemplo desta modernidade competitiva que se instala no atual cenário do espaço público brasileiro, temos o confronto dos pentecostais contra os afro-brasileiros. Este assinala a ruptura com a assimilação católica-sincrética, substituindo a tolerância complacente deste molde pelo confronto equivalente, que instaura produção de individualidades, intersubjetividades, diferenciação de identidades e concorrência (SOARES, 1993).

Portanto, dois estilos, um tradicional e um moderno, encontram-se operantes na história e na cultura brasileira, de forma que a relação entre matriz sincrética em continuidade e contexto histórico em transformação engendrem modalidades de sincretismo e de competição, de totalidade e de individualidade.

Toda essa tensão de composições/polarizações realizadas na fricção do campo religioso brasileiro com a sociedade maior, constrói nossa configuração de espaço público. Nele, os agentes religiosos procuram alianças e desenvolvem estratégias (tácitas ou explícitas) junto aos poderes públicos, tanto executivos (esferas de decisão do poder), quanto judiciários (lócus das demandas jurisprudenciais), mas também às mídias (internet e marketing). Dois regimes de verdades percorrem essas tramas simultaneamente sociais e religiosas: o da tradição, acentuando totalidades e sincretismos e o da diferença, remarcando as descontinuidades e dissensos. Esses regimes atravessam o discurso e o comportamento dos atores religiosos, ora engendrando cosmologias e imaginário religioso em esferas sociais, como a da política, economia e a da sexualidade, ora contrabandeando cosmologia e imaginário dessas esferas seculares para dentro do domínio religioso. 
Aqui nossa intenção é articular o enfoque próprio das religiões e de suas relações mútuas, no que se convencionou atender pelo domínio de "campo religioso brasileiro" com a relação destas mesmas religiões com o espaço do poder, da produção e do conhecimento, enfim com o lugar público. Embora essa linha demarcatória funcione apenas do ponto de vista formal/didático, pois como disse Burity, na dinâmica de relacionalidade entre religião e sociedade/espaço público, a religião "passa a ser contestada (...) pelos seus outros (religiosos, jurídico-políticos (...) enquanto empresta seu léxico, suas táticas e sua semântica a processos políticos nos quais participa" (2018, p.61).

Compatibilizar então, um olhar para a religião que articule estes dois registros - o simbólico/espiritual e o político/público - parece ser o desafio. Para entendermos a relação entre dinâmica religiosa e espaço público; assim como, as implicações da presença da dimensão religiosa nesse espaço, é necessário problematizar o conceito de espaço público e seus derivados, laico e secular, não os tomando como naturalizados e reificados. Ou seja, exercer uma crítica em relação à noção de laico e secular como um ideal de público a ser seguido, totalmente emancipado do religioso, onde qualquer presença de religião signifique um abastardamento da condição imaculada do modelo. É preciso então, escapar da ideia normativa de laico e secular, como modelos através dos quais a realidade concreta é mensurada de forma positiva ou negativa "por aproximação ou distanciamento" em relação a este ideal (CAMURÇA, 2017 p. 859).

Neste particular, concordamos com Talal Asad de que o domínio do secular não deva ser pensado como espaço autônomo do religioso, mas, co-relacional a este (2003). E também como Casanova de que no dito processo de secularização ocidental, religioso e secular funcionaram como "fronteiriços e mutuamente condição um do outro" (2006, p. 10). Asad, por sua vez, nos fala de uma "inversão ideológica" onde primeiramente o "secular" fez parte do discurso teológico e em seguida o "religioso" foi construído pela política secular e o discurso científico (2003). 
Portanto, nossa perspectiva neste texto será, ao invés de contentarmos com a distinção laico/secular como instância em si mesma explicativa da relação entre esfera pública e dimensão religiosa, buscar compreender como os agentes religiosos e laicos se apropriam das regras legais/constitucionais da laicidade em função dos seus interesses e projetos (CAMURÇA, 2017, p.856-62). Processo este, gerando situações de controvérsias, confrontos, alianças e acomodações.

\section{Tensões e dissonâncias no espaço e na esfera pública brasileira}

A partir do exposto, constata-se que nos últimos anos no Brasil um recrudescimento religioso de ocupação da esfera pública no Brasil. Quadro diferenciado da antiga ocupação promovida pelo Catolicismo hegemônico. Agora, marcado pela competição entre as religiões e articulações múltiplas com as instituições públicas. Os grupos religiosos adentram ao espaço público utilizando recursos do mercado e da mídia ${ }^{13}$. Conforme ressaltou Ricardo Mariano ao analisar as eleições presidenciais de 2010, constatou-se que nos últimos pleitos os candidatos à presidência buscavam apoio de lideranças religiosas cristãs, com a presença visível destes em templos, a proliferação de discursos políticos marcados por temas da moral religiosa e evocação a símbolos sagrados e a pressão da parte dos religiosos para que os presidenciáveis assumissem publicamente certos compromissos morais e políticos favoráveis aos interesses destas igrejas (MARIANO, 2011).

Nesse sentido, os segmentos de ultradireita e conservadores formam alianças com igrejas e agentes religiosos de mesma extração ideológica, apoiados por redes midiáticas de tendência direitista. Com efeito, muitos líderes religiosos, como o deputado-pastor Marco Feliciano, vocalizam o mal-estar conservador de muitos setores da sociedade brasileira diante das conquistas de minorias sociais e seu empoderamento, refletidos em legislações e políticas públicas. Por outro lado,

\footnotetext{
${ }^{13}$ Nas disputas no âmbito do campo religioso contemporâneo, os meios de comunicação têm desempenhado um papel primordial. Ao alocar os complexos mecanismos dos meios de comunicação para estabelecer e manter sua posição dentro do campo religioso, ao mesmo tempo em que procuram expandir-se em outras instâncias, as instituições adaptam suas estratégias de representação às exigências da Modernidade (MARTINO, 2003).
} 
setores de centro-esquerda e esquerda, movem-se no espectro contrário, apoiados por redes de mídias alternativas, empunhando bandeiras laicas. Por fim, os eleitorados de centro flutuam, alternando compromissos e alianças, aproximandose das posições de direita e/ou de esquerda, dependendo das conjunturas e temáticas em pauta na dimensão pública. Eis porque podermos constatar neste quadro social a existência de tipos híbridos e articulações distintas entre as esferas sócio-ético-econômicas, tais como: liberal na economia e conservador nos costumes; liberal na economia e nos costumes; libertário nos costumes e comunitário na economia.

Por um processo de pressão e contrapressão, a inserção dos agentes sociais religiosos (grupos e indivíduos) no espaço público, não necessariamente aumenta o poderio normativo da religião. Em outras palavras, a hegemonia do religioso na determinação de comportamentos e ações individuais e coletivas, provoca também a reorganização de grupos não-religiosos, podendo aprofundar percepções laicizadas. Por outro lado, o irromper de forças laicas e movimentos identitários organizados no cenário público desde a Constituinte de 1988, na conquista de direitos e garantia de políticas estatais de reconhecimento, despertou uma poderosa reação de um enraizamento religioso até então apolítico que passou a usar sua pujança e representatividade na população em instrumento de poder.

Além disso, na dinâmica desse circuito de trocas, não é apenas o espaço público que se vê atravessado por valores religiosos, institucionalizados ou não. As próprias formas de viver a religiosidade e as agências de administração do sagrado são afetadas pelas estruturas centrais da modernidade e das tecnologias laicas e seculares que estruturam o espaço público.

O ritmo das mutações e retrações na sociedade e na sua dimensão pública também influi na configuração do religioso, ou seja, na forma desigual como a identidades religiosas são construídas: tanto as soft, marcadas por heterogeneidades e liberdades estéticas, sexuais, morais ("igrejas inclusivas", comunidades religiosas de lésbicas e gays), quanto as hard, marcadas por 
compromissos fundamentalistas e por homogeneidades estéticas e morais (comunidades religiosas evangélicas, carismáticas ou de outras religiões).

Dessa forma, sociedades laicas e seculares terminam por conviver com efervescências religiosas dos mais variados tipos: místicas (fuga do mundo), mágicas (encantamentos utilitários) e éticas (ação no mundo). Dessas tipologias rapidamente esboçadas, as religiões de compromisso ético são as que mais acentuam tensões com as esferas de valores institucionalmente diferenciadas e movidas por lógicas próprias: arte, ciência, política, economia, sexualidade e intelectualidade (WEBER, 2002). Donde se conclui que religiões marcadas por exigências éticas (dogmático-conservadoras) carregam em si aporias quando estão no espaço público, esse marcado por estruturas de construção da verdade e de consensos sociais muito diferentes das construções religiosas da verdade e dos seus consensos.

Por isso, uma das características centrais da inserção do conservadorismo religioso no espaço público é o seu envolvimento em controvérsias. Dentre as várias controvérsias que inseriram os religiosos conservadores no debate público mobilizando mídias e suas parcelas de apoio na sociedade, projetos de lei e investidas no executivo - estão aquelas relacionadas a sua rejeição à extensão de direitos civis aos casais homoafetivos. Da mesma maneira, os debates em torno da moral/sexual envolvendo as igrejas cristãs tradicionais em confronto com instâncias governamentais e ONGs ligadas a saúde, a sexualidade e direitos reprodutivos. Dessa forma, as políticas públicas relativas à família e à saúde da mulher tornam-se objeto de disputas dos religiosos conservadores, empenhados na defesa de representações naturalizadas da moral, da sexualidade e da concepção de vida. Por seu lado os segmentos da diversidade de gênero, sexual e de costumes se colocam do lado das transformações próprias das modernas sociedades democráticas ocidentais. Ou seja, da reivindicação e conquista da igualdade de direitos cidadão; tratamento político e social isonômico do ponto de vista do Estado e de suas políticas públicas. 
Assim, a investida de grupos religiosos objetivando restaurar a "velha ordem" visa refrear as políticas públicas de extensão de direitos civis e reprodutivos a mulheres, gays, lésbias e trans. Nesses grupos religiosos, não se vê disposição para o diálogo, já que muitos deles se veem como "guerreiros ou soldados de Deus" e na mão de um “guerreiro” há sempre uma espada desembainhada, ou não.

Por outro lado, o acirramento das posições religiosas dogmáticas produz efeito contrário: o engajamento dos grupos defensores da diversidade no cenário da política. Não é possível dissociar estes dois elementos: as campanhas moralizadoras dos evangélicos/carismáticos e como contrapartida a organização associativa e política destes. Podem-se citar, como ilustração, o perfil de políticos assumindo sua condição homossexual ou de organizações que lutam em favor dos direitos de minorias, junto com outros grupos e lideranças ${ }^{14}$.

Embora seja inegável que a religiosidade cristã influencie a pauta dos legislativos e executivos, suas tentativas impositivas de propor valores estritamente religiosos para o mundo social e cultural sofrem também uma rejeição de parcelas expressivas da opinião pública. Em geral, as ações religiosas colonizadoras do meio laico estão baseadas em visões internas de grupamentos cristãos que costumam defender valores específicos como ideias universais. Assim, noções de "missão", "vocação" e "verdade", oriundas do meio cristão tradicional (de católicos e evangélicos) confrontam grupos militantes laicos, gerando uma zona de tensão marcada pelo embate entre valores civis constitutivos do que seja o "bem comum" e os valores morais particulares a estes religiosos, vividos enquanto absolutos.

\footnotetext{
${ }^{14} \mathrm{Um}$ pequeno exemplo dessa questão ocorreu nas câmaras municipais de duas cidades paraibanas, Pilar e Cajazeiras. Nelas, dois vereadores são eleitos como representantes do núcleo LGBTI+ (lésbicas, gays, bissexuais, travestis e transexuais). Segundo reportagem veiculada eletronicamente: "Em Pilar, Geraldo Costa da Silva, ou Shirley Costa, 51 anos de idade, tornou-se a primeira travesti a assumir um cargo eletivo na política do Estado. Eleita pelo partido progressista (PP) é adepta do candomblé há 38 anos e conhecida como 'Mãe Shirley'. Na cidade de Cajazeiras, sertão paraibano, o ex-secretário de Cidadania e Ação Social da cidade, Jucinério Félix, homossexual assumido e militante nas causas LGBT's, foi eleito vereador com um discurso de combate a homofobia [...] Mas, dos 156 candidatos LGBT's a vereador espalhados no Brasil, apenas 5 deles se elegeram nas eleições municipais de 2012, número menor que na eleição passada de 2010, quando 8 se elegeram.". Reportagem escrita em 01/01//2013 por Hylo Pereira em jornal eletrônico, Portal Correio. Link: http://portalcorreio.uol.com.br/politica/politica/legislativo/2013/01/01.
} 
Dentro de uma fundamentação do modelo do Estado Democrático de Direito e laico, algumas análises apontam dois tipos de limites para essa influência religiosa no nosso espaço público: o assistencialismo/clientelismo como forma estreita de tratar a cidadania e a ênfase em interesses econômicos e políticos imediatos do grupo, o corporativismo. Mas se formos analisar a experiências da "linha de frente" da intervenção religiosa no espaço público, ou seja, a atuação das "frentes parlamentares religiosas", a evangélica em particular, a partir de seus projetos, pode-se constatar um esforço de alargamento dos seus interesses. Das ações iniciais para assegurar a concessão de TVs e rádios para a comunicação de suas mensagens, facilidades de alvarás para construção de locais de culto e obtenção de recursos do Estado para prover sua clientela religiosa, passa-se a algo mais amplo. Pode se perceber uma vontade de introjetar nos domínios do "way of life" da modernidade secular, sua nova versão de "Neocristandade". A ambição e o universo de temáticas onde é projetado esta mensagem religiosa recobre um leque cada vez maior, em relação ao espaço que a Ciência Política já chamou de "superestrutura da sociedade", ou seja, as dimensões: ambientais, educacionais, sanitárias, esportivas, culturais, etc.

Constata-se, por outro lado, ainda que em menor número, ações de grupos religiosos (tanto cristãos ligados a Teologia da Libertação e Pastorais populares do catolicismo, quanto de religiões afro-brasileiras, do protestantismo histórico, e dos grupos neoesotéricos) com entrada no espaço público, produzindo ações com um timbre republicano e com responsabilidades ambientais e sociais.

Compreender o espaço público brasileiro (através do vetor religião/laicidade) na sua complexidade é vê-lo como um campo de interação, debates e disputas entre interesses sociais, políticos, religiosos e corporativos. Nesta arena discursiva, funciona a interação de projetos referentes a direitos sociais, políticos e civis, tanto das minorias, quanto das maiorias sociais. Dentro desta dinâmica, nos meios de comunicação social de massa e eletrônicos, que são elementos de forte influência sobre o espaço público, a religião faz-se fortemente presente. Evangélicos (neo) pentecostais e católicos carismáticos/midiáticos 
predominam em canais e programas religiosos, que multiplicam e diversificam-se, absorvendo linguagens e tecnologias modernas, combinando antigos bens simbólicos com o estilo da modernidade capitalista.

Nos meios políticos, a atuação institucional intensifica-se: Frentes Parlamentares Evangélicas na Câmara Federal e nas Câmaras Estaduais ocupam comissões, encaminham projetos, negociam o varejo político. Nos meios sociais urbanos, as grandes marchas e mobilizações em massa, lideradas por evangélicos e católicos, procuram traçar sobre o território público (SANTANA, 2014). Esses eventos veiculam uma moralidade cristã, entendida mais como natural inclinação de homens e mulheres, e menos como mais uma das muitas opções coletivas e pessoais de vida, ética, estética e moral. No atacado e no varejo, as igrejas pentecostais e neopentecostais são atores extremamente ciosos de seus interesses simbólicos e materiais.

Enquanto, líderes, igrejas e poderosas corporações evangélico/pentecostais pugnam pela (re)emergência do poder confessional (controle religioso de partidos políticos, bancadas e frentes evangélicas, movimentos de "Maioria Moral”), outros segmentos religiosos cristãos, afro-brasileiros e esotéricos se envolvem em novos arranjos, decorrência de experimentações surgidas de novas subjetividades na cultura, na sociedade e na religião em ambientes urbanos.

De um lado, identidades lastreadas numa certeza atemporal/transcendente que incide sem mediações na história e na sociedade, de outro, atores e discursos que fazem justamente o movimento contrário, negando essa identidade rígida, em função de múltiplas referências, libertárias, místico-ecológicas, de valorização de minorias oprimidas.

Assim, posições dogmáticas, de regimes de verdade inquestionáveis, porque baseados em revelações autorizadas do transcendente, irrompem como resposta aos processos de liquefação de identidades e fronteiras culturais, econômicas e religiosas. Assiste-se então, reações diferenciadas as mutações engendradas nas 
sociedades modernas: segurança $\mathrm{x}$ liberdade, certeza $\mathrm{x}$ incerteza ontológicas, que operam, de um lado, em organizações molares, de outro, em composições moleculares. Se a segurança ontológica dos movimentos tradicionais está calcada na tradição, numa visão (pós) moderna, horizontes de certeza só podem ser enunciados numa perspectiva "de curto prazo" e "fragmentada" (GIDDENS, 2001; HERVIEU-LEGER, 1993).

Dessa forma, é necessário compreender o comportamento dos múltiplos atores e discursos contemporâneos (igrejas, conservadoras e sua política confessional, comunidades científicas e suas políticas públicas), seus instrumentos e veículos (mídias de massa e cibernéticas) e seus dispositivos (religiosos, científicos, políticos). Compreender dentro de que contornos discursam e agem os grupos, movimentos e indivíduos religiosos e laicos no espaço público. Observar os contextos dos movimentos globalizantes, atravessados por novas formas de textos e intertextualidades, de comunicação e antagonismos.

Em contextos conservadores de jogos de linguagem, de poder e de hegemonia, afirma-se uma (má) fé, por exemplo, na tentativa de equivaler homossexualidade à pedofilia, no nível da linguagem. Na ordem do discurso como projeto político-moral, essa operação é vocalizada por muitos grupos religiosos cristãos de direita. E em nome de um absoluto, moral, cultural ou religioso, procura-se um porto seguro de desejos, crenças, ações, justificativas e construções discursivas. Por outro lado, as práticas religiosas desinstitucionalizadas e o individualismo propulsor de várias formas subjetivas de ser religioso, se espraiam em mais variados matizes e combinações, crescem em diversos segmentos sociais, contribuindo para dinâmicas contraditórias.

Enfim, de um lado, se assiste a nostalgia da tradição, produtora de autoritarismos e fundamentalismos reemergentes, de outro, destradicionalizações variadas e desregulações diversas 


\section{Esforço teórico diante da complexidade religiosa e secular no espaço público e no Estado brasileiro}

Como os arranjos sociais e institucionais se encontram em processo de efervescência no mundo e no nosso país e os instrumentos conceituais lutam para dar conta de toda essa complexidade, exigem-se releituras, reinterpretações, renovações dos conceitos generalizantes e estáticos tais como: religioso/secular; sagrado/profano etc. Ou ainda, é preciso pensar numa superação das grades molares dos conceitos, em prol de uma linguagem fluente e inovadora. Dessa forma, o que se observa nas mobilizações sociais e culturais no ambiente público, não são sujeitos abstratos e universais, mas múltiplos atores em existência interessada, desde as ofensivas conservadoras de grupos católicos carismáticos e evangélico-pentecostais até as proposições laicas, da igualdade de gênero, raça, religiões levantadas por militantes sociais e grupos identitários. Num mundo de redes, fluxos e refluxos, de fundamentalismos religiosos e ideologias libertárias, para que se compreenda tanto as vozes emergentes, quanto as recolocações das tradicionais, gerando tensões, dissonâncias e conflitos entre estas, impõe-se o esforço de repaginar a teoria clássica; assim como de recombinar ênfases e autores a serviço da compreensão deste panorama contraditório, mas implicado entre si.

As noções que aqui utilizamos para análise do que chamamos de configurações e mosaico de posições que compõe nosso espaço público - ora interagindo ora se antagonizando - buscam articular tanto a interpretação compreensiva da sociologia weberiana e da hermenêutica antropológica com a perspectiva crítica da teoria marxiana e bourdieusiana, acrescida de uma imaginação e experimentação quase colada ao nível da conjuntura e dos acontecimentos.

Portanto, a presença diferenciada/desigual das religiões no espaço público (católicos/evangélicos majoritários, afro-brasileiros, orientais e new ages, minoritários) e dos grupos laicos e identitários (de gênero, etnia, território) exige uma percepção analítica que detecte mecanismos de poder, de submissão, 
discriminação, verbalização de preconceitos, mas também a produção de novas sociabilidades, invenções e significados para a vida social e simbólica.

É fato, que desde as eleições de 2018 com a chegada ao poder de uma coligação de extrema direita legitimada por forças religiosas cristãs reacionárias, assistimos a um gradativo desmonte de uma política laica de direitos humanos e reprodutivos, de reconhecimento a minorias religiosas, étnicas, de gênero, enfim da aceitação da pluralidade e diversidade na esfera e no espaço público, proveniente da Constituição de 1988.

Isto impõe uma inflexão ao quadro que estivemos traçando enquanto panorama, ao longo do texto: de uma polaridade de posições entre o ativismo religioso conservador, a postura religiosa dita progressista e as iniciativas de grupos laicos e identitários, isto tudo perpassado pelo que estamos chamando de tensões e dissonâncias.

$\mathrm{Na}$ verdade, esta (re)conquista por parte de uma direita cristã do poder político e intervenção crescente no Estado, leva a ao estabelecimento de uma preeminência do conservadorismo na máquina do governo e através dele em ações na sociedade.

Resta as forças libertárias e progressistas laicas e religiosas o lugar da resistência a tais medidas. Mas mesmo assim, a instituição representante da maior religião no país, a Igreja Católica através da sua hierarquia, a $\mathrm{CNBB}$, respaldada no pontificado do Papa Francisco, tem dado demonstrações de equilíbrio no que diz respeito aos direitos sociais, ambientais, de gênero e de raça. São demonstrações disto, as posições tomadas no Sínodo da Amazônia, a favor de indígenas, ribeirinhos e quilombolas; assim como na recente pandemia do Covid-19, a posição a favor do isolamento social e a disponibilização de seus templos para servirem de hospitais. 


\section{Conclusão}

Finalizamos o texto com a aplicação dos instrumentos teóricos/conceituais que enunciamos na introdução deste artigo para entender o jogo das polaridades e (a)ssimetrias envolvendo os grupos religiosos conservadores, dos religiosos liberais e dos setores laicos presentes no espaço público brasileiro.

A compreensão de laicidade como pluriconfessionalidade (BLANCARTE, 2011) - concepção, esta, extraída de uma percepção êmica de regime laico pelas religiões cristãs majoritárias (evangélicos e católicos conservadores) - permite que estas justifiquem o direito a uma presença pública, sem as amarras de submissão a neutralidade de leis universais/constitucionais, acima do seu "direito religioso". A este consórcio religioso, podem até juntar-se, no caso brasileiro, setores conservadores do Espiritismo e do Judaísmo. As dissonâncias aparecem quando setores laicos e religiosos que aceitam as mediações jurídicas, científicas, sanitárias, educacionais, questionam a decisão de colocar os dogmas e verdades religiosas acima do que é o "bem comum” organizador de uma sociedade.

Por outro lado, destacamos a construção da laicidade dentro de transformações históricas que imprimem na modernidade "direitos e deveres" para com as religiões. Processo que foi classificado por Philippe Portier de "laicidade de reconhecimento" e "laicidade de integração" (2010). Se examinarmos o caso brasileiro, dentro destas duas fases e modelos de laicidade (que o autor criou para a análise da França), de acordo com o perfil de cada uma de nossas religiões, teremos adequações e concordâncias, mas também tensões e dissonâncias. Para o autor francês, a laicidade no seu país, caminhou de uma situação de separação estrita entre religião e Estado, para o reconhecimento das religiões por parte do mesmo ("lógica do reconhecimento") e por fim para a exigência de integração das religiões nos parâmetros da lei maior e da cidadania ("lógica da integração"). No caso do Brasil, todas as religiões (tradicionais, moderadas ou libertárias) querem ser reconhecidas pelo Estado e gozar de benefícios enquanto instâncias de assistência à população. Aqui podem encontrar resistência de setores laicistas que consideram 
que toda sorte de religião deve se situar no âmbito do privado e isto também pode gerar tensões e dissonâncias.

Por outro lado, as principais correntes evangélicas/pentecostais e setores católicos carismáticos, não querem aceitar as políticas estatais de valorização de concepções e práticas de gays, lésbicas e transexuais; assim como das cosmologias de indígenas, quilombolas quando estas entram em desacordo com seus dogmas e ditas verdades bíblicas. Estas saúdam a "lógica do reconhecimento" por parte do Estado em relação a elas, mas rejeitam sua possibilidade de "integração" aos parâmetros da Constituição brasileira e suas leis universais garantistas e protetivas para a diversidade da população.

A conquista do governo federal em 2018, representa para estas forças religiosas reacionárias a oportunidade de alterar a lei e introduzir dogmas e valores particulares do "seu" cristianismo - tais como o "Estatuto da família", "Estatuto do Nascituro" e "Escola sem partido" - numa direção monocausal (ainda que reivindicada e justificada como proveniente de "maioria moral" da população) contrária a pluralidade do universal.

No entanto, mais um desdobramento das dissonâncias parece afetar o que parecia ser a inexorável rota religiosa conservadora de se assenhorar do poder e domesticar populações inteiras às suas diretrizes. Uma recente pesquisa da prestigiosa revista formadora de opinião Valor Econômico aponta que dentre as instituições a perder crédito e confiança de parcelas da sociedade, estão as religiões ${ }^{15}$.

Também durante a pandemia do Covid 19, o comportamento religioso conservador (evangélico/pentecostal, católico/carismático) tendeu a discrepar das orientações da Organização Mundial de Saúde, partindo de um negacionismo à ciência em prol do "milagre" e da "proteção divina" contra o vírus. A maneira como

\footnotetext{
${ }^{15}$ “as igrejas [...] começam a apresentar sinais de desgaste. A confiança incondicional [...] recuou de 35,2\% para $29,7 \%$ desde 2018 ". Disponível, https://valor.globo.com/politica/noticia/2020/06/15/aumenta-rejeicao-a-ideias-golpistas-mostra-pesquisa.ghtml Acesso em: 28 jun. 2020.
} 
este imaginário religioso obscurantista se revelou - seja através de intervenção direta, dos seus líderes, parlamentares, ou indireta, pela sua presença ideológica no governo Bolsonaro - tomou a forma de uma "guerra cultural", que disseminou entre seus fiéis "teorias da conspiração", como a inoculação da população pelo "vírus chinês", o perigo da vacina também contaminadora. Além disso questionaram a eficácia do uso de máscara e de evitação dos ajuntamentos para conter a transmissão viral. Tudo isso, com exortações para manutenção dos templos abertos, se contrapondo às políticas de isolamento como atentatórias à liberdade religiosa.

No Brasil contemporâneo, portanto, as disputas de sentido em torno das noções do que seja o papel da ciência, da cidadania e da religião no espaço público, configurando os contornos do que seja a nossa laicidade e nosso Estado Laico, permanecem acesas e atravessadas por tensões e dissonâncias.

\section{REFERÊNCIAS}

ASAD, Talal. Formations of the secular: christianity, islam, modernity. Stanford: Stanford University Press, 2003.

AZZI, Riolando. O estado leigo e o projeto ultramontano: história do pensamento católico no Brasil IV. São Paulo: Paulus, 1994.

BERGER, Peter. Múltiplos altares da modernidade: rumo a um paradigma da religião numa época pluralista. Petrópolis: Vozes, 2017.

BERGER, Peter. O dossel sagrado: elementos para uma teoria sociológica da religião. São Paulo: Paulinas, 1985.

BLANCARTE, Roberto. América Latina: entre pluriconfessionalidad y laicidade. Civitas: revista de ciências sociais, Porto Alegre, v. 11, n. 2, p. 182-206, 2011.

BURITY, Joanildo. A onda conservadora na política brasileira traz o fundamentalismo ao poder? In: ALMEIDA, Ronaldo; TONIOL, Rodrigo (org.). Conservadorismos, fascismos e fundamentalismos: análises conjunturais. Campinas: Editora da Unicamp, 2018. p.15-66.

BURITY, Joanildo. Redes, parcerias e participação religiosa nas políticas sociais no Brasil. Recife: Massangana, 2006. 
CAMURÇA, Marcelo Ayres. A questão da laicidade no Brasil: mosaico de configurações e arena de controvérsias. Horizonte, Belo Horizonte, v. 15, n. 47, p. 855-886, jul.-set. 2017.

CAMURÇA, Marcelo Ayres. Entre sincretismos e "guerras santas": dinâmicas e linhas de força do campo religioso brasileiro. Revista da USP, São Paulo, n. 81, p. 173-185, mar.maio 2009.

CASANOVA, José. Rethinking secularization: a global comparative perspective. The Hedgehog Review, Charlottesville, v. 8, n. 1-2, p. 7-22, 2006.

CATROGA, Fernando. Entre deuses e Césares: secularização, laicidade e religião civil. Coimbra: Almedina, 2010.

ENNES, Marcelo Alario; MARCON, Frank. Das identidades aos processos identitários: repensando conexões entre cultura e poder. Sociologias, Porto Alegre, v. 16, n. 35, p. 274-305, abr. 2014. Disponível em:

http://www.scielo.br/scielo.php?script=sci_arttext\&pid=S151745222014000100010\&lng=en\&nrm=iso. Acesso em: 5 jul. 2020.

GIDDENS, Anthony. Em defesa da sociologia: ensaios, intepretações e tréplicas. São Paulo: Editora Unesp, 2001.

GIUMBELLI, Emerson. A presença do religioso no espaço público: modalidades no Brasil. Religião e Sociedade, Rio de Janeiro, v. 28, n. 2, p. 80-101, 2008.

GIUMBELLI, Emerson. O fim da religião: dilemas da liberdade religiosa no Brasil e na França. São Paulo: Attar Editorial, 2002.

GIUMBELLI, Emerson. Símbolos religiosos em controvérsias. São Paulo: Terceiro Nome, 2014.

HABERMAS, J. Mudança estrutural na esfera pública. Rio de Janeiro: Tempo Brasileiro, 2003.

HERVIEU-LEGER, Daniele. La religion pour mémoire. Paris: Éditions du Cerf, 1993.

MACHADO, Maria das Dores Campos. Religião, cultura e política. Religião e Sociedade, Rio de Janeiro, v. 32, n. 2, p. 29-56, 2012.

MARIANO, Ricardo. Laicidade à brasileira: católicos, pentecostais e laicos em disputa na esfera pública. Civitas, Porto Alegre, v. 11, n. 2, p. 238-258, maio-ago. 2011.

MARTIN, David. Tongues of fire: the explosion of protestantism in LatinAmerica. Oxford: Brasil Blackwell, 1990.

MARTINO, Luís Mauro Sá. Mídia e poder simbólico: um ensaio sobre comunicação e campo religioso. São Paulo: Paulus, 2003. 
MONTERO, Paula. Controvérsias religiosas e esfera pública: repensando a religião como discurso. Religião e Sociedade, v. 32, n. 1, p. 167-183, 2012.

MONTERO, Paula. Religião, pluralismo e esfera pública no Brasil. Novos Estudos CEBRAP, n. 74, p. 47-65, 2006.

OLIVEIRA, Pedro Ribeiro. Estruturas da Igreja e conflitos religiosos. In: SANCHIS, Pierre (org.). Catolicismo: modernidade e tradição. São Paulo: Edições Loyola, 1992. p. 41-66.

PORTIER, Philippe. A regulação estatal da crença dos países da Europa Ocidental.

Religião e Sociedade, Rio de Janeiro, v. 31, n. 2, p. 11-28, 2011.

PORTIER, Philippe. Regulação estatal da religião na França (1880-2008): ensaios de periodização. Rever, São Paulo, p. 24-47, 2010.

RANQUETAT JÚNIOR, César Alberto. A invocação do nome de Deus nas Constituições Federais Brasileiras: religião, política e laicidade. Cultura y Religión, v. 7, n. 2, p. 86101, 2013.

SANCHIS, Pierre. O campo religioso contemporâneo no Brasil. In: ORO, Ari Pedro; STEIL, Carlos Alberto (org.). Globalização e religião. Petrópolis: Vozes, 1997. p. 103-117.

SANTANA, Raquel. O som da marcha: evangélicos e espaço público na marcha para Jesus. Religião e Sociedade, Rio de Janeiro, n. 2, p. 210-231, 2014.

SOARES, Luiz Eduardo. A guerra dos pentecostais contra o afro-brasileiro: dimensões democráticas do conflito religioso no Brasil. Comunicações do ISER, Rio de Janeiro, ano 12, n. 44, p. 43-50, 1993.

WEBER, Weber. Rejeições religiosas do mundo e suas direções. In: WEBER, Weber. Ensaios de sociologia. 6. ed. Rio de Janeiro: LTC, 2002. 